Research Article

\title{
Energy properties of bamboo biomass and mate co-products
}

\author{
Fernando Rusch ${ }^{1,2}$ (D) Raul de Abreu Neto ${ }^{1,3}$ (i) $\cdot$ Danielle de Moraes Lúcio ${ }^{1}$ (i) $\cdot$ Éverton Hillig ${ }^{1}$ (i)
}

Received: 13 January 2021 / Accepted: 15 April 2021

Published online: 01 May 2021

(c) The Author(s) 2021 OPEN

\begin{abstract}
Fossil fuels are being replaced by clean energy sources. Lignocellulosic biomass is considered an eco-friendly alternative, as it is a renewable raw material with high energy potential. In this context, the aim of this study was to determine the biomass energy properties of three bamboo species and mate. Thus, three species of bamboo (Bambusa vulgaris Var. Vittata, Dendrocalamus asper and Phyllostachys aurea) and Ilex paraguariensis co-products (branches and sticks) were performed. The particle size, basic density, moisture content volatiles content, ashes content, fix carbon, gross and net calorific value and energy density of these biomasses were evaluated. The biomasses analyzed here were considered suitable for energy purposes, in general, these presented volatile content between 75 and $85 \%$, fixed carbon content between 15 and $25 \%$ and ash content close to $1 \%$. Average fix carbon content of all analyzed biomass was $16.13 \%$. Ash content of Phyllostachys aurea, branches of Ilex paraguariensis and Dendrocalamus asper presented lower values, average of $1.63 \%$. Bambusa vulgaris and llex paraguariensis sticks presented higher values, average of $2.65 \%$. Phyllostachys aurea presented gross calorific value higher than, average of $19.35 \mathrm{MJ} \mathrm{kg}^{-1}$. Bambusa vulgaris, Dendrocalamus asper, Ilex paraguariensis branches and sticks presented statistically equal values. Bambusa vulgaris, Dendrocalamus asper, Phyllostachys aurea showed net calorific value higher to the other analyzed materials and did not present statistical difference. Basic energy density of Phyllostachys aurea was higher to bamboo species. Ilex paraguariensis showed the lowest values with no statistical difference for branches and sticks.
\end{abstract}

\section{Article highlights}

- Knowledge of biomass properties enables the use of residues in bioenergy production as an eco-friendly alternative.

- Bamboo and Mate co-products have desirable characteristics and potential to produce bioenergy.

Keywords Ash content · Energy density · Gross calorific value · Bioenergy

$\triangle$ Fernando Rusch, fe_rusch@yahoo.com.br | ${ }^{1}$ Forest Engineering Department, Midwestern State University (UNICENTRO), Rodovia PR 153, km 7, Riozinho, Irati, PR 84.500-000, Brazil. ${ }^{2}$ MULTIBAMBOO, Areia, PB, Brazil. ${ }^{3}$ Science and Technology of Wood, Federal University of Lavras, Lavras, Brazil.

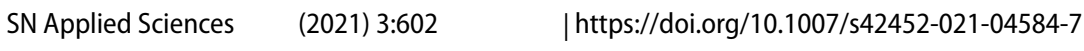




\section{Introduction}

Energy consumption has been increasing in recent decades across the globe and, due to the dependence on fossil-based fuels and its high emission of pollutants, the levels of greenhouse gases in the atmosphere also increase [1]. As an eco-friendly alternative, fossil fuels are being replaced by clean energy sources, encouraging a search for more cost-effective renewable fuels and promoting sustainable development [2]. In this scenario, lignocellulosic biomass is considered as a renewable raw material with high energy potential[3].

Despite the bioenergy potential, lignocellulosic biomass is still an unexplored resource. In some cases, if the destination is poorly conducted, it is considered a waste, causing environmental problems such as air pollution (during open burning), water courses pollution and problems in industries, such as occupation of large areas [4]. According to Organization for Economic Cooperation and Development (OECD), Brazil ranked 13th in the $\mathrm{CO}_{2}$ emitters list. Even with one of the best carbon monoxide compensation energy matrices in the world, the country has pledged to reduce its greenhouse gas (GHG) emissions by more than 35\% until 2020 [5], by National Policy on Climate Change (PNMC).

Use of waste in sustainable energy production is an important part of future energy concept. Transforming biomass, an important renewable resource, into bioenergy of low production cost and low emission of acid gases, provides a continuous source of energy, independent of climatic and seasonal changes, in addition, it can be stored and used when needed [6-9].

Brazil has potential for biomass production as an energy source, with the most widely used raw materials being wood residues (shavings and sawdust). However, the proper use of biomass energy resources requires some precautions, such as the shape and size of its particles and biomass high moisture content [10]. Thus, biomass from grass species, agricultural residues and residues from food industry become increasingly important [7], among which we can highlight bamboo species and co-products of mate.

Bamboo is a promising material for energy use [11]. In Brazil there are large commercial plantations, with emphasis on the northeast region and natural fragments in the Amazon interior. In addition, it can be processed with the same equipment used in tree species [12].

Mate (Ilex paraguariensis A. St. Hil.) is economically exploited in about 480 municipalities in Paraná states, Santa Catarina, Rio Grande do Sul and Mato Grosso do Sul. It occupies an area of more than 110 thousand hectares, cultivated in approximately 180 thousand rural properties. This culture generates more than 700 thousand jobs [13]; however, two types of waste are largely generated: (1) branches, from the pruning process [14]; (2) thin sticks, from the processing of raw material [15, 16].

Brazilian production of fresh leaves in 2014 was 935 thousand tons [17], around $7 \%$ of this material become a co-product of sticks at the end of processing in herbaceous industries. This represents approximately 65 thousand tons per year, of which can be used as an alternative to biomass energy. Energetic properties of biomass are directly related to the energy potential. It is essential to know these properties to optimize production efficiency and improve the quality of the final product, highlighting: basic density, fix carbon content, volatile, ashes and gross calorific value, moisture and ash content, in addition to particle size and shape, moisture absorption capacity and resistance to processing $[18,19]$.

The energy potential is estimated through the gross calorific value (GCV) and the net calorific value (NCV). GCV is defined as the amount of energy released (per unit mass or volume) in stoichiometric combustion of a combustible material. It basically depends on the chemical composition of each fuel, in general, the higher the GCV, the more efficient the combustion. The study of material energetic properties can be useful in deciding how to use this waste, and suggest it as a potential alternative source of energy.

This study aimed to determine the biomass energy properties of bamboo species and the co-products of mate (branches and sticks of harvesting process).

\section{Materials and methods}

\subsection{Bamboo chip production}

Three species of bamboo were used, Bambusa vulgaris Var. Vittata, Dendrocalamus asper e Phyllostachys aurea. Thirty individuals were selected with uniformity in height, stem diameter and wall thickness, in addition to a straight geometric shape (to facilitate the chip chipping process) to produce bamboo chips. Mature individuals were selected, aged between three and four years, estimated in their external appearance.

Final dimensions of bamboo chips were approximately $3 \mathrm{~mm} \times 20 \mathrm{~mm} \times 40 \mathrm{~mm}$ (thickness, width and length). Subsequently, the material was dried in the open air, in a ventilated environment, until it reached the moisture content.

Figure 1 shows stems harvested, equipment used to produce bamboo chips and quantity of chips produced. Co-products of mate (Ilex paraguariensis) resulting from production of herb and/or compost for chimarrão 

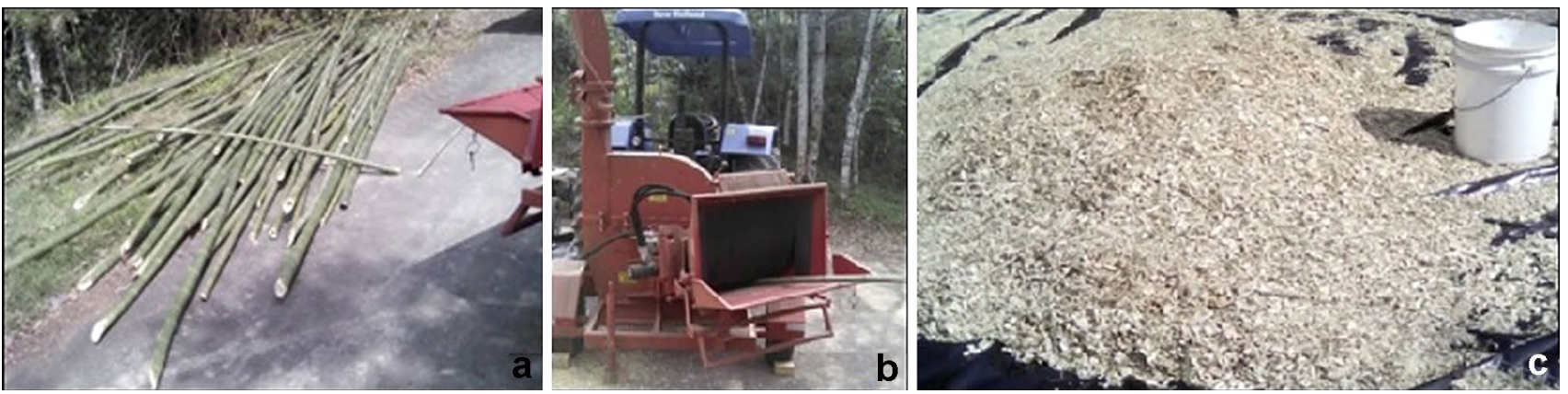

Fig. 1 Bamboo chip production process. a Bamboo stems (thirty units); b Forest Chipper coupled to the hydraulic system of a farm tractor used to cut bamboo stems into chips; c total volume of chips produced

(Brazilian tea) were branches and sticks resulting from the processing of leaves and thin branches.

\subsection{Material preparation}

Material previously chopped was crushed in a hammer mill (Willye TE 650) and then used in analysis of particle size, proximate chemical analysis, gross and net calorific value and energy density. Three repetitions were performed for each biomass sample, totaling about $1 \mathrm{~kg}$ of material (Fig. 2).

\subsubsection{Particle size analysis}

Biomass of different materials was sieved and separated in three sizes by sieve meshes $(<35,35-60,>60$ mesh). Material used to determine proximate chemical analysis and calorific value was classified between 35 and 60 mesh, as determined by Brazilian Regulatory Standard (NBR) 6923 [20].

\subsubsection{Basic density}

Basic density was determined by the hydrostatic method, by immersion in water, as described in NBR 11941 [21].

\subsubsection{Moisture content}

Samples were placed in an oven at $103 \pm 2{ }^{\circ} \mathrm{C}$ until constant mass. Moisture (Mc) content was obtained in Eq. (1), by difference between the wet mass $(\mathrm{m} 1)$ and dry mass (m2) weight of samples. Moisture content of the samples was determined according to ASTM E 870-82 standard [22].

$M c=\frac{(m 1-m 2)}{m 1} \times 100$

Mc: Moisture content of biomass (\%); $\mathrm{m} 1$ : wet mass (g); $\mathrm{m} 2$ : dry mass (g).

\subsection{Proximate chemical analysis}

Proximate chemical analysis was performed according to ASTM D 1762-84 standard [23] to determine the volatiles content, ashes content and fix carbon. Samples of $2.0 \mathrm{~g}$ were used in porcelain crucibles. All tests were performed in triplicate.

\subsubsection{Volatile content}

Volatile content was determined using dry samples, previously kept in oven (Ni 1384 model) for seven minutes at
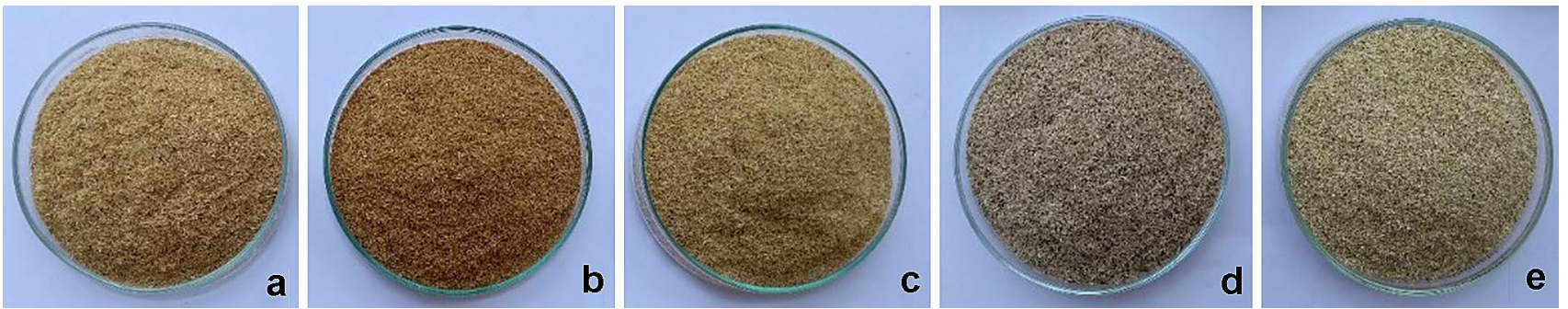

Fig. 2 Alternative materials used in the experiment. Bamboo: Bambusa vulgaris. Var. Vittata (a), Dendrocalamus asper (b), Phyllostachys aurea (c); mate (llex paraguariensis): branches (d) and thin sticks (e) 
$950^{\circ} \mathrm{C}$. Subsequently, samples were cooled in a desiccator and then weighed.

\subsubsection{Ash content}

Ash content was determined according to ASTM D 176284 [23] standard with the same material used in analysis of volatile content, which were taken to the oven at temperature of $750^{\circ} \mathrm{C}$, until it reaches constant mass. At the end of this process, it is assumed that only ashes remain inside the crucible, result of combustion of organic components and oxidation of inorganic.

\subsubsection{Fix carbon content}

Fix carbon content ( $\mathrm{Fcc}$ ) was determined by the difference between values of volatile content and ash content.

\subsection{Energetic analysis}

Gross calorific value (GCV) was determined according to ASTM D240 [24], using IKA WORKS digital calorimetric bomb, model C 5000. The measurements were taken in duplicates, using an analytical balance for weighing. Net calorific value (NCV) was determined by GCV subtracting the energy used to evaporate the hydrogen constituting the fuel in the form of water.

\subsubsection{Energy density}

Energy density was determined by the relationship between the value of gross calorific value and the basic density of analyzed materials, by Eq. (2).

$B E D=\frac{(G C V)}{B d} \div 1000$

BED: Basic energy density (GJ $\mathrm{m}^{-3}$ ); GCV: gross calorific value $\left(\mathrm{MJ} \mathrm{Kg}^{-1}\right)$; Db: basic density $\left(\mathrm{kg} \mathrm{m}^{-3}\right)$.

\subsection{Data analysis}

Assumptions of data normality and homogeneity of variance were tested, considering the average values obtained from physical, energetic properties and proximate chemical analysis of five alternative lignocellulosic materials, in three repetitions. ANOVA and Tukey mean comparison test at $5 \%$ probability of error were performed in a completely randomized design.

\section{Results and discussion}

Granulometric distribution varied between bamboo and mate species (Table 1). All materials analyzed had volumes between 58.6 and $66.2 \%$ in recommended granulometry. Granulometry in class above 60 mesh showed variation between species, with higher values for llex paraguariensis sticks and Phyllostachys aurea, and the lowest value for Ilex paraguariensis branches. Highlighting the influence of materials size on the biomass density.

\subsection{Basic density, moisture content and proximate chemical analysis}

The data relating to basic density, moisture content and approximate analysis are shown in Table 2 . It was observed in this study that the biomasses of Bambusa vulgaris and Phyllostachys aurea had similar basic density, average of $0.624 \mathrm{~g} \mathrm{~cm}^{-3}$. Followed by Dendrocalamus asper with $0.543 \mathrm{~g} \mathrm{~cm}^{-3}$. Branches and sticks of Ilex paraguariensis show similar density, average of $0.406 \mathrm{~g} \mathrm{~cm}^{-3}$.

Bamboo density average observed in this study corroborate those found by Vale et al. [25] who analyzed $B$. vulgaris in different positions (bottom, middle and top) with one and three years of age. The authors obtained mean values varying between 0.505 and $0.609 \mathrm{~g} \mathrm{~cm}^{-3}$ over height, individuals were studied at three years of age, while Brito et al. [26] reported density $0.687 \mathrm{~g} \mathrm{~cm}^{-3}$. Berndsen et al. [27] observed that the basic density of bamboo varied with age and position along the stalks, despite its height and total diameter being reached in a short period of time. Melo et al. [28] in a study with Bambusa vulgaris in stems, approximately four years old, observed density values close to $0.630 \mathrm{~g} \mathrm{~cm}^{-3}$. Santos et al. [18] found for Bambusa vulgaris var. Vittata $0.462 \mathrm{~g} \mathrm{~cm}^{-3}$, while for Dendrocalamus asper, the values were $0.604 \mathrm{~g} \mathrm{~cm}^{-3}$. Santin et al. [29] found mean values close to $0.400 \mathrm{~g} \mathrm{~cm}^{-3}$ for basic density of mate pruning branches aged 12-36 months.

Table 1 Distribution of different biomasses in granulometric classes (\%)

\begin{tabular}{|c|c|c|c|}
\hline \multirow[t]{2}{*}{ Raw material } & \multicolumn{3}{|l|}{ Mesh } \\
\hline & $<35$ & $35-60^{a}$ & $>60$ \\
\hline Bambusa vulgaris & 16.2 & 66.2 & 17.6 \\
\hline Dendrocalamus asper & 18.1 & 65.5 & 16.4 \\
\hline Phyllostachys aurea & 8.3 & 64.2 & 27.5 \\
\hline Ilex paraguariensis (branches) & 30.0 & 58.6 & 11.4 \\
\hline Ilex paraguariensis (sticks) & 12.3 & 60.8 & 26.9 \\
\hline
\end{tabular}

${ }^{\mathrm{a}} 35$ and 60 mesh materials are recommended for chemical analysis, NBR 6923 [20] 
Table 2 Average values of basic density, moisture content and proximate analysis

\begin{tabular}{llllll}
\hline Materials & Bd & Mc & Fcc & Vc & Ac \\
\hline Bambusa vulgaris & $0.602 \mathrm{a}$ & $8.50 \mathrm{a}$ & $16.03 \mathrm{ab}$ & $81.42 \mathrm{ab}$ & $2.55 \mathrm{~b}$ \\
Dendrocalamus asper & $0.543 \mathrm{~b}$ & $8.93 \mathrm{ab}$ & $17.16 \mathrm{a}$ & $81.04 \mathrm{a}$ & $1.80 \mathrm{a}$ \\
Phyllostachys aurea & $0.647 \mathrm{a}$ & $9.25 \mathrm{~b}$ & $15.94 \mathrm{ab}$ & $82.61 \mathrm{ab}$ & $1.45 \mathrm{a}$ \\
Ilex paraguariensis (branches) & $0.422 \mathrm{c}$ & $10.67 \mathrm{c}$ & $15.08 \mathrm{~b}$ & $83.26 \mathrm{~b}$ & $1.66 \mathrm{a}$ \\
Ilex paraguariensis (sticks) & $0.391 \mathrm{c}$ & $8.99 \mathrm{~b}$ & $16.44 \mathrm{ab}$ & $80.80 \mathrm{a}$ & $2.76 \mathrm{~b}$ \\
\hline
\end{tabular}

$B d$ basic density $\left(\mathrm{g} \mathrm{cm}^{-3}\right), M c$ moisture content (\%), Fcc fixed carbon content (\%), Vc volatile content (\%), Acash content (\%). Averages followed by the same letter do not differ by Tukey test, at $5 \%$ probability of error
Carvalho et al. [14] observed a density of approximately $0.400 \mathrm{~g} \mathrm{~cm}^{-3}$ of mate branches.

In comparison with wood species used for energy generation, the density of Bambusa vulgaris is similar to those reported by [4], ranging from 0.471 to $0.619 \mathrm{~g} \mathrm{~cm}^{-3}$ for different species of Eucalyptus. Santos et al. [18] observed basic density of $0.482 \mathrm{~g} \mathrm{~cm}^{-3}$ for $E$. urograndis, values higher than those verified in this study for mate branches and sticks.

Average moisture content of different materials was $9.27 \%$. All the analyzed materials showed moisture content below $11 \%$ and can be used for energy generation [30]. Statistical differences were found between the moisture content in the different species. Lowest moisture content was observed for Bambusa vulgaris. Mate branches showed statistically higher humidity values.

However, when analyzing the use of wood residues for energy generation, mean values of moisture content of $16.12 \%$ were found for Pinus spp wood shavings [31]. Rousset et al. [32] in a study performed with mature culms of Bambusa vulgaris species, over three years old. The authors reported values of $20.2 \%$ humidity. Lin et al. [33] found values between 6.98 and $7.9 \%$ of TU for dry bamboo residues of the genus Phyllostachys.

Average fix carbon content of all analyzed biomass was $16.13 \%$. Among the species, there was variation in fix carbon content between species, Dendrocalamus asper showed a value significantly higher than other materials and $1.5 \%$ higher than the average. Ilex paraguariensis (branches) showed a significantly lower value, 2.3\% below the average.

Amount of heat generated by waste is determined by fix carbon content. In general, the higher the fix carbon content, the better the quality of material for burning, as this fuel will burn more slowly and with less flame formation [18, 26]. Rambo et al. [11], Vale et al. [25] and Rousset et al. [32] found a fix carbon content of 17.20, 17.66 and $17.75 \%$, respectively, in different bamboo species.

Value of fix carbon content of Bambusa vulgaris and Phyllostachys aurea observed in this study corroborates those found in the literature [34]. Sette Junior et al. [35] evaluated hybrid of Eucalyptus grandis $\times$ Eucalyptus urophylla and found fix carbon content of $17.5 \%$. These results suggest proximity between the results of fix carbon found in the literature for tree species used in energy forests and the data found in this study, highlighting the biomass of Dendrocalamus asper.

Volatile content was higher for mate branches, 83.26\%, compared to the sticks, $80.80 \%$. Average values of the different bamboo species did not differ statistically from those found in mate sticks. Bamboo species showed higher volatile content, when compared to the values observed by Rambo et al. [11], Vale et al. [25] and Rousset et al. [32], the authors found values of $81.08,78.14$ and $80.13 \%$, respectively. Sette Junior et al. [35] found $82.2 \%$ volatile content for the sample of Eucalyptus grandis $x$ Eucalyptus urophylla hybrid.

Volatiles play an important role during the initial stages of combustion, biomass with a high volatile content is easier to ignite and burn. Biomass generally presents high levels of volatile materials [36], despite these combustion advantages, this characteristic can make it difficult to control the combustion process. Pyrolysis and carbonization processes can decrease the volatile content of a biomass. Increase in carbonization temperature favors the maintenance of lower final levels of volatile [37].

Ash content formed two groups. Biomass of Phyllostachys aurea, branches of Ilex paraguariensis and Dendrocalamus asper composed the group with lowest ash content, with an average of $1.63 \%$. The averages of these materials did not differ statistically. The second group was composed of Bambusa vulgaris and Ilex paraguariensis sticks, an average of $2.65 \%$.

Mate biomass sticks had $2.76 \%$ ash content, considered high for an arboreal species. This greater amount of ash can be explained by the young material, presenting a high content of inorganic mineral constituents, necessary for the nutrition of plant portions with intense physiological activity.

Rambo et al. [11] and Rousset et al. [32] in a study with biomass of bamboo species observed ash contents of 1.71 and2.12\%, respectively. Moreira (2012) [38] found 
ash content increasing with age, due to the accumulation of siliceous bodies. Santin et al. [29] in a study with mate branches found mean ash content close to $3.9 \%$. High ash content contributes to the reduction of biomass HCV, considering that it is a mineral content not activated in the combustion process [39]. Sette Junior et al. [35] evaluated hybrids of Eucalyptus grandis $\times$ Eucalyptus urophylla and found ash content close to $0.3 \%$, this value corroborates those found by Santos et al. [18].

Biomass with a high ash content can cause corrosion on the inner wall of boilers, resulting in higher maintenance costs [40]. High ash content decreases calorific value and causes energy loss [41]. Firewood is the solid fuel most used in boilers, with around $1 \%$ ash content, a good index for not damaging boilers and furnaces [42].

Knowledge of the proximate chemical analysis composition of biomass provides the material's characteristics as a fuel. Fuels with a low fix carbon content and a high content of volatile materials burn quickly, requiring a short period of time for integral decomposition. Although the ash content has a negative correlation with biomass calorific value [43].

\subsection{Energetic analysis}

Energy potential was assessed by biomass combustion. Gross calorific value (GCV) and net calorific value (NCV) were estimated. Basic energy density (BED) can also be an indicator of biomass energy potential and corresponds to the product between the gross calorific value and the basic density. Table 3 shows values of the energetic properties of the different biomasses analyzed.

Phyllostachys aurea presented gross calorific value (GCV) superior to other biomasses analyzed, average of $19.35 \mathrm{MJ} \mathrm{kg}^{-1}$. Followed by Bambusa vulgaris, Dendrocalamus asper, Ilex paraguariensis branches and sticks, these values did not differ statistically.

Bambusa vulgaris, Dendrocalamus asper, Phyllostachys aurea showed NCV superior to the other analyzed materials and did not present statistical difference. Ilex

Table 3 Average values of the energetic properties of the different biomasses analyzed

\begin{tabular}{llll}
\hline Treatment & GCV & NCV & BED \\
\hline Bambusa vulgaris & $17.99 \mathrm{~b}$ & $16.42 \mathrm{a}$ & $10.83 \mathrm{~b}$ \\
Dendrocalamus asper & $18.70 \mathrm{ab}$ & $16.47 \mathrm{a}$ & $10.15 \mathrm{~b}$ \\
Phyllostachys aurea & $19.35 \mathrm{a}$ & $16.47 \mathrm{a}$ & $12.52 \mathrm{a}$ \\
Ilex paraguariensis (branches) & $18.69 \mathrm{ab}$ & $16.13 \mathrm{c}$ & $7.89 \mathrm{c}$ \\
llex paraguariensis (sticks) & $18.75 \mathrm{ab}$ & $16.28 \mathrm{~b}$ & $7.33 \mathrm{c}$ \\
\hline
\end{tabular}

GCV gross calorific value $\left(\mathrm{MJ} \mathrm{Kg}^{-1}\right), N C V$ Net calorific value (MJ $\left.\mathrm{Kg}^{-1}\right), B E D$ basic energy density $\left(\mathrm{GJ} \mathrm{m}^{-3}\right.$ ) paraguariensis sticks and branches showed the lowest NCV values, with an average of 16.28 and $16.13 \mathrm{MJ} \mathrm{kg}^{-1}$, respectively.

Basic energy density (DEb) of Phyllostachys aurea was superior to the other analyzed materials, followed by bamboo species Bambusa vulgaris and Dendrocalamus asper, which did not present statistical difference. Smallest DEb was observed for llex paraguariensis, with no statistical difference for branches and sticks.

GCV average value corroborates the results found in the literature. Rambo et al. [11], Guarnetti and Coelho [12], Vale et al. [25] and Brito et al. [26] observed values close to $18.32,16.74,18.24$ and $17.65 \mathrm{MJ} \mathrm{kg}^{-1}$. The found GCV average of $18.94 \mathrm{MJ} \mathrm{kg}^{-1}$ for mate pruning branches [29].

Coniferous forest species generally present superior $\mathrm{GCV}$, this occurs due to the higher contents of resin, waxes and oils and mainly of lignin [44]. Wood shavings from Pinus sp. and $A$. angustifolia species presented mean GCV values of 17.23 and $17.32 \mathrm{MJ} \mathrm{Kg}^{-1}$, respectively [45].

Biomass GCV correlates with the data obtained from proximate chemical analysis [46]. In general, with the $1 \%$ increase in the fix carbon content, there is GCV increase of $0.39 \mathrm{MJ} \mathrm{kg}^{-1}$. In addition, with an increase of $1 \%$ in ash content, GCV reduces by $0.2 \mathrm{MJ} \mathrm{kg}^{-1}[1,36]$.

These results help to understand the higher ash content of Bambusa vulgaris, which has the lowest GCV. The mineral elements of this species do not contribute to the combustion process, reducing its efficiency. A similar condition is observed in relation to mate sticks.

The found an average NCV value of 17.00 and $16.91 \mathrm{MJ}$ $\mathrm{kg}^{-1}$ for $A$. Angustifolia and Pinus sp. species, respectively [45]. Observed an average NCV of $18.20 \mathrm{MJ} \mathrm{kg}^{-1}$ in saw dust, costan and refills from Pinus taeda L. (residues from wood processing) [47].

DEB values observed in this study corroborate the results found in the literature. Santin et al. [29] in a study with mate pruning branches found DEB of $7.57 \mathrm{GJ} \mathrm{m}^{-3}$. Santos et al. [18] in a study with bamboo species and wood of the Eucalyptus grandis $\times$ Eucalyptus urophylla hybrid found an average DEB value of $9.68 \mathrm{GJ} \mathrm{m}^{-3}$ and $9.80 \mathrm{GJ}$ $\mathrm{m}^{-3}$, respectively. Moura et al. [47] in a study with harvest residues and wood processing from Pinus taeda L. (sawdust, costan and refill), found an average DEB value of 2.98 and $4.81 \mathrm{GJ} \mathrm{m}^{-3}$, respectively.

Biomasses considered suitable for energy purposes, in general, have volatile content between 75 and $85 \%$, fix carbon content between 15 and $25 \%$ and ash content below $1 \%[34,42]$. Bamboo biomass has the potential to produce bioenergy, with high calorific value and low moisture content [11].

The biomasses analyzed in this study showed higher ash content, however adequate values of volatile material and fix carbon, equivalent to that observed for wood 
from different forest species. These materials tend to have rapid combustion, where most of their mass is burned in the gases form and the lowest proportion in solid form (residual carbon), providing satisfactory energy potential. To reduce the ash content, an alternative is the addition of materials from the wood productive chain in the process of burning, such as forest (harvest) and industrial residues (sawdust, shavings, charcoal fines, etc.).

\section{Conclusions}

Basic density and fixed carbon content were higher at the bamboo species than in mate biomass. Compared to wood, the average values of the biomasses studied was similar for fixed carbon content and volatile content, on the other hand, it was higher for basic density (only for bamboo species), moisture content and ash content.

Biomasses analyzed here were considered suitable for energy purposes, with values of the main properties close to the energy biomasses found in the literature. Energy analysis showed that the gross calorific value was similar for all biomasses, while net calorific value and basic energy density were higher for bamboo species. Compared to wood species, basic energy density was higher for bamboo and lower for sticks and branches of mate.

Acknowledgements The authors would like to thank the Coordenação de Aperfeiçoamento de Pessoal de Nível Superior - Brasil (Capes; finance code 001), for partially financing the first author's doctoral research.

Authors' contributions RUSCH F and HILLIG É conceived and designed the study; RUSCH F and LÚCIO DM performed the study; RUSCH F and HILLIG É analyzed the data; RUSCH F, LÚCIO DM and ABREU NETO R contributed to materials/analysis tools; RUSCH F, HILLIG É, LÚCIO DM and ABREU NETO R wrote and revised the paper.

\section{Declaration}

Conflict of interest The authors declare no conflict of interest

Open Access This article is licensed under a Creative Commons Attribution 4.0 International License, which permits use, sharing, adaptation, distribution and reproduction in any medium or format, as long as you give appropriate credit to the original author(s) and the source, provide a link to the Creative Commons licence, and indicate if changes were made. The images or other third party material in this article are included in the article's Creative Commons licence, unless indicated otherwise in a credit line to the material. If material is not included in the article's Creative Commons licence and your intended use is not permitted by statutory regulation or exceeds the permitted use, you will need to obtain permission directly from the copyright holder. To view a copy of this licence, visit http://creativecommons. org/licenses/by/4.0/.

\section{References}

1. Nejat $P$, Jomehzadeh $F$, Taheri MM, Gohari M, Majid MZA (2015) A global review of energy consumption, $\mathrm{CO}_{2}$ emissions and policy in the residential sector (with an overview of the top ten $\mathrm{CO}_{2}$ emitting countries). Renew Sustain Energy Rev 43:843-862. https://doi.org/10.1016/j.rser.2014.11.066

2. Jung SJ, Kim SH, Chung IM (2015) Comparison of lignin, cellulose, and hemicellulose contents for biofuels utilization among 4 types of lignocellulosic crops. Biomass Bioenergy 83:322-327. https://doi.org/10.1016/j.biombioe.2015.10.007

3. Ullah K, Kumar Sharma V, Dhingra S, Braccio G, Ahmad M, SOFIA $S$ (2015) Assessing the lignocellulosic biomass resources potential in developing countries: a critical review. Renew Sustain Energy Rev 51:682-698. https://doi.org/10.1016/j.rser.2015.06. 044

4. Protásio TP, Bufalino L, Tonoli GHD, Couto AM, Trugilho PF, Guimarães Júnior M (2011) Relação entre o poder calorífico superior e os componentes elementares e minerais da biomassa vegetal. Pesq Flores Bras 31:113-122. https://doi.org/10.4336/2011.pfb. 31.66 .113

5. EPE (2013) Balanço energético nacional: ano base 2012. Governo Federal, Brasília. URL https://www.epe.gov.br/sites-pt/publi cacoes-dados-abertos/publicacoes/PublicacoesArquivos/publi cacao-129/topico-101/Relat\%C3\%B3rio\%20Final\%202013.pdf. Accessed 16 Mar 2021

6. Chou C, Lin S, Lu W (2009) Preparation and characterization of solid biomass fuel made from rice straw and rice bran. Fuel Process Technol 90:980-987. https://doi.org/10.1016/j.fuproc.2009. 04.012

7. Stelte W, Clemons C, Holm JK, Sanadi AR, Ahrenfeldt J, Shang L, Henriksen UB (2011a) Pelletizing properties of torrefied spruce. Biomass Bioenergy 35(11):4690-4698. https://doi.org/10.1016/j. biombioe.2011.09.025

8. Stelte W, Holm JK, Sanadi AR, Barsberg S, Ahrenfeldt J, Henriksen UB (2011b) A study of bonding and failure mechanisms in fuel pellets from different biomass resources. Biomass Bioenergy 35(2):910-918. https://doi.org/10.1016/j.biombioe.2010.11.003

9. Stelte W, Sanadi AR, Shang L, Holm JK, Ahrenfeldt J, Henriksen UB (2012) Recent developments in biomass palletization: a review. Bioresources 7(3):4451-4490

10. Almeida NA, Ângelo H, Gentil LVB, Silva JCGL (2011) Demanda de briquete de madeira. Floresta 41:73-78. https://revistas.ufpr. br/floresta/article/view/21183/13975

11. Rambo MKD, Schmidt FL, Ferreira MMC (2015) Analysis of the lignocellulosic components of biomass residues for biorefinery opportunities. Talanta 144:696-703. https://doi.org/10.1016/j. talanta.2015.06.045

12. Guarnetti RL, Coelho ST (2014) Cogeração de eletricidade utilizando bambu no Brasil: aspectos técnicos, econômicos e ambientais. J Biomassa BR 3(14):3-8

13. EMBRAPA (2015) Sistema de Produção da Erva Mate. Soluções tecnológicas. Embrapa Florestas. URL https://www.embrapa.br/ busca-de-solucoes-tecnologicas/-/produto-servico/2093/siste ma-de-producao-de-erva-mate. Acessed 16 Nov 2018

14. Carvalho AG, Andrade BG, Cabral CPT, Vital BR (2015) Efeito da adição de resíduos de poda da erva-mate em painéis aglomerados. Rev Árvore 39(1):209-214. https://doi.org/10.1590/010067622015000100020

15. Guiotoku M, Lazaris V, Dallago RM, Magalhães WLE (2008) Utilização de Palitos de Erva-Mate na Produção dePainéis de Aglomerado. Embrapa Florestas, Colombo

16. Souza JT, Talgatti M, Menezes WM, Haselein CR, Santini EJ, Beltrame $\mathrm{R}$ (2018) Propriedades não destrutivas do MDP produzido 
com partículas de madeiras e de llex paraguariensis. Sci For 46(119):507-518. https://doi.org/10.18671/scifor.v46n119.17

17. IBGE (2016) Produção Agrícola Municipal (PAM). Instituto Brasileiro de Geografia e Estatística, Rio de Janeiro

18. Santos DRS, Sette Júnior CR, Silva MF, Yamaji FM, Almeida RA (2016) Potencial de espécies de Bambu como fonte energética. Sci For 44(111):751-758. https://doi.org/10.18671/scifor.v44n1 11.21

19. Soares VC, Bianchi ML, Trugilho PF, Pereira AJ, Hofler J (2014) Correlações entre as propriedades da madeira e do carvão vegetal de híbridos de eucalipto. Rev Árvore 38(3):543-549. https:// doi.org/10.1590/S0100-67622014000300017

20. ABNT (1981) NBR 6923: Carvão vegetal - Amostragem e preparação da amostra. Associação Brasileira de Normas Técnicas. https://www.abntcatalogo.com.br/norma.aspx?ID=7377. Acessed 16 Mar 2021

21. ABNT (2003) NBR 11941. Determinação da densidade básica. Associação Brasileira de Normas Técnicas. https://www.abntc atalogo.com.br/norma.aspx?ID=002494\#: :text=Esta\%20Nor ma\%20especifica\%20o\%20m\%C3\%A9todo,ou\%20na\%20for ma\%20de\%20cavacos Acessed 16 Mar 2021

22. ASTM (2006) $870-82$. Standard test methods for analysis of wood fuels. American Society for Testing and Materials, West Conshohocken

23. ASTM (2013) D1762-84. Standard Test Method for Chemical Analysis of Wood Charcoal. American Society for Testing and Materials, West Conshohocken

24. ASTM (2017) D240. Standard test method for heat of combustion of liquid hydrocarbon fuels by bomb calorimeter. American Society for Testing and Materials, West Conshohocken

25. Vale AT, Moreira ACO, Martins IS (2017) Avaliação do Potencial Energético de Bambusa vulgaris em Função. da Idade Floram 24:e00123314. https://doi.org/10.1590/2179-8087.123314

26. Brito JO, Tomazello Filho M, Salgado ALB (1987) Produção e caracterização do carvão vegetal de espécies e variedades de bambu. IPEF 36:13-17

27. Berndsen RS, Klitzke RJ, Batista DC, Nascimento EM, Ostapiv F (2010) Propriedades físicas do bambu-mossô (Phyllostachys pubescens Mazel ex $\mathrm{H}$. de Lehaie) emdiferentes idades e posições do colmo. Floresta 40:183-192. https://doi.org/10. 5380/rf.v40i1.17109

28. Melo RR, Stangerlin DM, Souza AP, Cademartori PHG, Schneid E (2015) Propriedades físico-mecânicas de painéis aglomerados madeira-bambu. Ciênc Rural 45(1):35-42. https://doi.org/10. 1590/0103-8478cr20120970

29. Santin D, Gonçalves Sobrinho MB, Carneiro ACO, Benedetti EL, Barros NF (2017) Phosphorus fertilization and harvest intervals influence energetic and physical properties of briquettes and large branches of mate. Rev Árvore 41(1):e410110. https://doi. org/10.1590/1806-90882017000100010

30. Furtado TS, Ferreira JC, Brand MA, Neves MD (2012) Correlação entre teor de umidade e eficiência energética de resíduos de Pinus taeda em diferentes idades. Rev Árvore 36:577-582. https://doi.org/10.1590/S0100-67622012000300020

31. Calegari L, Foelkel CEB, Haselein CR, Andrade JLS, Silveira P, Santini EJ (2005) Características de algumas biomassas usadas na geração de energia no Sul do Brasil. Biomass Energy 2(1):37-46

32. Rousset $P$, Aguiar $C$, Labbé N, Commandré JM (2011) Enhancing the combustible properties of bamboo by torrefaction. Bioresour Technol 102(17):8225-8231. https://doi.org/10.1016/j.biort ech.2011.05.093

33. Lin LD, Chang FC, Ko CH, Wang CT (2016) Bamboo-derived fuel from Dendrocalamus latiflorus, Phyllostachys makinoi, and Phyllostachys pubescens waste. BioRes 11(4):8425-8434
34. Balduino Junior AL, Balduino TY, Friederichs $G$, Cunha AB, Brand MA (2016) Energetic potential of bamboo culms for industrial and domestic use in Southern Brazil. Ciênc Rural 46(11):19631968. https://doi.org/10.1590/0103-8478cr20160233

35. Sette Junior CR, Freitas PC, Freitas VP, Yamaji FM, Almeida RA (2016) Production and characterization of bamboo pellets. Bioscience 32(4):922-930. https://doi.org/10.14393/BJ-v32n4 a2016-32948

36. Demirbas A (2004) Combustion characteristics of different biomass fuels. Prog Energy Combust Sci 30:219-230. https://doi. org/10.1016/j.pecs.2003.10.004

37. Araújo ACC, Costa LJ, Braga PPC, Guimarães Neto RM, Rocha MFV, Trugilho PF (2018) Propriedades energéticas da madeira e do carvão vegetal de Cenostigma macrophyllum: subsídios ao uso sustentável. Pesq Flor Bras 38:e201701546. https://doi.org/ 10.4336/2018.pfb.38e201701546

38. Moreira ACO (2012) Caracterização de Bambusa vulgaris Schard. exj.c. wendl. var. vulgaris, e dos resíduos de caldeira no processo de conversão térmica de energia. Dissertation, University of Brasília

39. Brand MA (2010) Energia de biomassa florestal. Interciência, Rio de Janeiro

40. Hupa M, Karlström O, Vainio E (2017) Biomass combustion technology development: it is all about chemical details. Proc Combust Inst 36:113-134. https://doi.org/10.1016/j.proci.2016.06. 152

41. Hoffmann BS, Szklo A (2011) Integrated gasification combined cycle and carbon capture: a risky option to mitigate $\mathrm{CO}_{2}$ emissions of coal-fired power plants. Appl Energy 88(11):3917-3929. https://doi.org/10.1016/j.apenergy.2011.04.002

42. Vale AT, Gentil LV, Gonçalez JC, Costa AF (2007) Caracterização energética e rendimento da carbonização de resíduos de grãos de café (Coffea arabica L.) e de madeira (Cedrelinga catenaeformis Duke). Cerne 13(4):416-420

43. Brun EJ, Bersch AP, Pereira FA, Silva DA, Barba YR, Dorini JJRD (2018) Caracterização energética da madeira de três materiais genéticos de Eucalyptus sp. Floresta 48:87-92. https://doi.org/ 10.5380/rf.v48i1.51673

44. Francescato V, Antonini E, Bergomi LZ, Metschina C, Schnedl C, Krajnc N, Koscik K, Gradziuk P, Nocentini G, Stranieri S (2012) Manual de combustibles de madera producción requisitos de calidad comercialización. Avebiom, Valladolid

45. Schmatz MJ, Siqueira JAC, Nogueira CEC, Souza SNM, Tokura LK, Menezes KL, Santos DB (2016) Evaluation of the gross and net calorific value of residues of wood pine and araucaria from reforestation. Afr J Agric Res 11(41):4157-4161. https://doi.org/ 10.5897/AJAR2016.11345

46. Dias JMCS, Souza DT, Braga M, Onoyama MM, Miranda CHB, Barbosa PFD, Rocha JD (2012) Produção de briquetes e péletes a partir de resíduos agrícolas, agroindustriais e florestais. Embrapa, Brasília pp 132. https://www.infoteca.cnptia.embra pa.br/handle/doc/952626. Accessed 16 Mar 2021

47. Moura MS, Silva DA, Rochadelli R, Santos RC (2012) Estimativa de poder calorífico e caracterização para uso energético de resíduos da colheita e do processamento de Pinus taeda. Floresta 42(2):325-334. https://doi.org/10.5380/rf.v42i2.26593

Publisher's note Springer Nature remains neutral with regard to jurisdictional claims in published maps and institutional affiliations. 